\title{
2.1. RELATIONSHIP BETWEEN ORGANISATIONAL JUSTICE AND ORGANISATIONAL CITIZENSHIP BEHAVIOUR: EXAMINING THE MEDIATING ROLE OF JOB SATISFACTION
}

\begin{abstract}
Summary
The relationship between organizational justice perceptions, job satisfaction, and Organizational citizenship behaviour (OCB) from the responses of 267 employees in the manufacturing sector showed that interpersonal justice positively influenced all dimensions of OCB. Among the justice factors, informational justice had a greater influence on job satisfaction than distributive justice, procedural justice, or interpersonal justice. The effect of job satisfaction on OCB was most significant on civic virtue, followed by courtesy, altruism, conscientiousness, and sportsmanship. The mediation analysis showed that job satisfaction fully mediated the relationship between organizational justice and OCB. Therefore, job satisfaction is a stronger predictor of citizenship behaviours than justice perceptions.
\end{abstract}

Keywords: job satisfaction, manufacturing sector, organizational citizenship behaviour, organizational justice

\section{Introduction}

Globalization and the advancement of technology has triggered much interest in organizational researchers to study the discretionary behaviour of employees at the workplace. As baby boomers retire, the core workforce in most organizations are dominated by Generation $\mathrm{X}$ and Generation $\mathrm{Y}$, who generally are less likely to remain in an organization for their entire working life. Being more techno-savvy, these workforce have access to information that provides career advancement opportunities which increase the incidence of leaving. Therefore, research on organizational citizenship behaviour (OCB) has attracted much attention as discretionary and extrarole behaviours of organizational citizens are instrumental for employee retention, job performance (Greenberg, 1988) and the survival of many organizations (Fassina et al., 2008). To understand what enhances OCB, various predictors of OCB have been examined, and among the most robust attitudinal predictors of OCB are employees 'perceptions of fairness (e.g. Colquitt et al., 2001; Hassan and Mohd Noor, 2008; Lo et al., 2006; Moorman, 1991; Organ and Konovsky, 1989; Podsakoff et al., 2000) and job satisfaction (e.g. Bateman and Organ, 1983; Smith et al., 1983; Williams and Anderson, 1991). As perceptions of fairness have been associated with job performance and $\mathrm{OCB}$, and $\mathrm{OCB}$ with job satisfaction, facilitating organisational justice becomes crucial.

Perceptions of organizational justice are widely recognized as an influential factor in employee attitudes at the workplace (Ramamoorthy and Flood, 2004). Employees who perceive unfairness is likely to limit their commitment to citizenship, whereas employees who perceive equity will contribute to the system through continued citizenship (Moorman, 1991; Podsakoff et al., 2000). Basically, organizational justice 
concerns three distinct, but related components of justice, namely, distributive, procedural, and interactional justice (Colquitt et al., 2001; Folger and Konovsky, 1989;). Tansky (1993) posits that procedural justice (perceived justice of the decisionmaking procedures) and fair treatment from managers and supervisors (interactional justice) seem to be the most important component to the relationship between justice and OCB. Others affirm that procedural justice accounts for a linear relationship with altruism (Farh et al., 1990) and altruism, courtesy, sportsmanship, and conscientiousness (Moorman, 1991).

Likewise, Robinson and Morrison (1995) argue that employees are less likely to engage in civic behaviour if they perceive that their employer had failed to fulfill employment obligations. Moorman (1991) emphasizes that interactional justice is the sole dimension of fairness to significantly relate to OCB while Giap et al. (2005) stress that the only significant correlation is that between altruism and interpersonal justice (sincerity and respectfulness of authority communication). Additionally, DeConinck (2010) asserts that in order to increase interactional justice, it is imperative for the supervisor to explain the procedure as well as to take questions from the employee regarding the process. In essence, employees are more likely to exhibit OCBs if they perceive that their organizations treated them fairly. But, do perceptions of organizational justice have similar relationships with OCB in a collectivist orientation culture like Malaysia?

In the Malaysian context, there is limited study on organizational justice and OCB, specifically with job satisfaction as a mediator. Furthermore, the limited literature available show that the findings of prior studies are rather ambiguous. Hassan and Mohd Noor (2008) assert that there is no significant relationship between organizational justice and extra-role behaviour in a high power distance and collectivistic society like Malaysia. Othman et al. (2005) establish that justice perceptions moderated the relationship between psychological contract violation and OCB. Despite being a high power distance country, where open expression of dissatisfaction is much constrained, interest in research on organizational justice in Malaysia has increased. Mohd Nasurdin and Soon (2011) examine the links between organizational justice (distributive justice and procedural justice) and job performance (task performance and contextual performance) while Hassan and Hashim (2011) explore the role of organizational justice in shaping teaching faculties' attitude (job satisfaction and commitment) and behavioural intention (turnover intention). However, limited studies in Malaysia have researched the relationship between organizational justice perceptions, job satisfaction and OCB in the manufacturing sector. Considering the job switching habits of the current Malaysian workforce, the question of how employee perceptions of organizational justice would be related to job satisfaction and OCB remains to be addressed. That question is the focus of this study.

\section{Relationship between organizational justice and organizational citizenship behaviour}

According to many studies, organizational justice seems to be a key determinant of OCB (Colquitt et al., 2001; Farh et al., 1990; Moorman, 1991; Organ and Konovsky, 1989; Organ and Ryan, 1995; Podsakoff et al., 2000). Meta-analytic data show positive 
correlations between both procedural and distributive justice and OCB (Colquitt et al., 2001). Fair procedures move people to support the needs of the group and augment OCB (Moorman and Blakely, 1995). Likewise, perceptions of interactional justice are instrumental in predicting OCB (Hassan and Jubari, 2010; Lazar et al., 2007; Moorman, 1991). Organ and Moorman (1993). Assert that procedural justice rather than distributive justice or job satisfaction explains more of the variance in OCB. Additionally, some studies suggest that perceptions of fairness may relate more strongly to altruism than to other OCB dimensions (Farh et al., 1990).

Skarlicki and Latham $(1996,1997)$ reiterate the importance of organizational justice and emphasize that training leaders in the principles of justice increases levels of perceived fairness and OCB. Tyler and Blader (2003) stress that employee sense of belonging in teams enhances perceptions of fairness and encourage citizenship behaviours'. As valued members of the team, employees realized the importance of OCB in enhancing their association in the team. Bateman and Organ (1983) argue that people seek to reciprocate those who benefit them. Once the employer initiates fair treatment of its employees, especially in relation to procedural and interactional justice, employees feel obligated to reciprocate (Blau, 1964; Homans, 1961) and employees reciprocate by exhibiting extra-role behaviours' (Robinson and Morrison, 1995). On the contrary, employees may adhere to negative reciprocity norms in restraining OCBs and only fulfill contractual obligations if they perceive unfair treatment. Hence Hypothesis 1: Employee perceptions of organizational justice positively affect the dimensions of OCB.

\section{Relationship between organizational justice and job satisfaction}

Some researchers argue that perceptions of justice and job satisfaction are indistinguishable (Organ et al., 2006), and conceptualize that justice perceptions strongly influence satisfaction at the workplace (e.g. Organ, 1988b). In contrast, Fassina et al. (2008) assert that justice and job satisfaction are likely distinguishable from each other as evaluation of justice and job satisfaction attitudes are qualitatively different. Nonetheless, numerous studies affirm that procedural fairness enhances job satisfaction (e.g. Colquitt, et al., 2001; Hendrix et al., 1999; Hooi, 2011; Igbaria and Greenhouse, 1992; Latham and Pinder, 2005). Likewise, Ismail et al. (2011) maintain that interactional justice significantly correlates with job satisfaction. Schaubroeck et al. (1994) contend that procedural justice is more strongly related than distributive justice to job satisfaction. In a meta-analytic study, Colquitt et al. (2001) affirm that all three justice dimensions were related to job satisfaction and organizational commitment. Accordingly, Hypothesis 2: Employee perceptions of organizational justice positively influence job satisfaction.

\section{Relationship between job satisfaction and organizational citizenship behaviour}

Prior empirical studies (e.g. Bateman and Organ, 1983; Organ and Konovsky, 1989; Organ and Ryan, 1995), and the conceptual rationale proposed by Organ (1988a, 1990) reveal a positive relationship between job satisfaction and OCB. Some research show that job satisfaction enhances extra-role behaviour (Organ, 1977) while others assert that the relationship between job satisfaction and $\mathrm{OCB}$ is one of social exchange 
(Bateman and Organ, 1983; Organ et al., 2006). Employees experiencing job satisfaction reciprocate through OCB and withdraw citizenship behaviours if they are dissatisfied. Murphy et al. (2002) found a correlation of between .40 and .67 in the job satisfaction-OCB relationship while Smith et al. (1983) established a correlation of .33 between job satisfaction and altruism and .29 between job satisfaction and compliance (conscientiousness). Thus, Hypothesis 3: Job satisfaction positively influences the dimensions of OCB.

\section{The role of job satisfaction in the justice-citizenship relationship}

Examining the mediating effect of job satisfaction in the justice-citizenship relationship, earlier studies maintain that organizational justice rather than job satisfaction is a more important predictor of OCB (Moorman, 1991; Organ, 1988a, 1990). Tansky (1993) claims that job satisfaction on its own relates positively to courtesy, civic virtue, altruism, and sportsmanship, but as a mediator in the justicecitizenship relationship, it is insignificant in predicting altruism and sportsmanship. This is probably attributed to the sizable correlations

between types of perceived fairness and job satisfaction (Fassina et al., 2008). However, studies have also indicated significant correlations between job satisfaction and OCB (e.g. Smith et al., 1983). Fassina et al. (2008) assert that job satisfaction may relate to OCB because it is distinctive from justice as an antecedent (Organ and Ryan, 1995); it mediates fairness-OCB relationships (e.g. Tansky, 1993); or it shares fairness as a common predictor (Farh et al., 1990). The inconclusiveness of the findings have hindered contributions to theory and research on $\mathrm{OCB}$, and hampered practical implications for managers (Fassina et al., 2008). Understanding if job satisfaction is a direct predictor of OCB or a mediator in the job satisfaction-OCB relationship, is therefore, imperative for advancement of theory development on OCB. Additionally, it would help guide practitioners to encourage OCB by either enhancing antecedents of job satisfaction or promoting favorable levels of perceived fairness. Fassina et al. (2008) further posit that the relationships among perceived fairness, job satisfaction, and OCB may be dependent on the types of justice and the dimensions of OCB. If this is indeed true, then managers would have an array of options to enhance OCB. Therefore, the relationships among perceived fairness, job satisfaction, and OCB need to be further explored. It is hypothesized that justice and job satisfaction are likely distinguishable from each other in their relationships to OCB. Hence,

Hypothesis 4: Job satisfaction mediates the relationship between organizational justice and OCB.

\section{Organizational justice and organizational citizenship behaviour in the Malaysian context}

Research on organization justice and OCB in Malaysia is slowly gaining momentum despite the collectivist and high power distance culture at the workplace. This is probably due to the evolution of new work ethics among the current generation of workforce. Gone were the days where loyalty and commitment to an organization was the norm. As such, organizations are embarking on various programs to instill OCB to retain talent workers. This has generated much interest among practitioners and 
academicians to research on antecedents of OCB to help enhance sustainability. In Western societies, it has been verified that organizational justice has a significant influence on OCB. But, research in non-western societies remains limited. A number of Malaysian scholars (e.g. Asgari et al., 2008; Hassan and Hashim, 2011; Hassan and Mohd Noor, 2008; Ishak and Alam, 2009; Khalid and Ali, 2005; Leow and Khong, 2009; Lo et al., 2006; Mohd Nasurdin and Soon, 2011, Othman et al., 2005) have examined the relationship between organizational justice and various organizational outcomes. Nonetheless, the outcomes are varied and the findings of similar studies are ambiguous.

Mohd Nasurdin and Soon (2011) examined the moderating role of age in the relationships between organizational justice (distributive justice and procedural justice) and job performance (task performance and contextual performance). The results gathered from a sample of 136 customer-contact employees within the telecommunications industry of Malaysia demonstrated that distributive justice had a significant and positive relationship with task performance while procedural justice was found to be significantly and positively related to contextual performance. Age, however, did not moderate the justice-performance relationships.

Hassan and Hashim (2011) analysed the role of organizational justice in shaping teaching faculties' attitude (job satisfaction and commitment) and behavioural intention (turnover intention). The findings from a sample of Malaysian nationals with tenure appointments and expatriates with contractual appointments drawn from four public universities in Malaysia revealed that except for job satisfaction, where Malaysians recorded significantly higher endorsement compared to expatriates, no significant difference was found between the two groups on perception of distributive, procedural, and interactional aspects of organizational justice, as well as organizational commitment and turnover intention. Interactional and distributive justice promoted expatriates' organizational commitment and/or intention to stay with the organization while procedural justice contributed to local employees' job satisfaction, organizational commitment, and turnover intentions. Another study by Hassan and Mohd Noor (2008) that examined the relationship between organizational justice and extra role behaviour showed no significant relationship between organizational justice components and extra role behaviour in the Malaysian context.

Leow and Khong (2009) studied the relationship and tested the interaction effects of organizational justice (distributive, procedural, and interactional) on organizational commitment among auditors serving in audit firms across Malaysia. The results showed that distributive, procedural and interactional perceptions of organizational justice positively influenced affective-normative commitment. Asgari et al. (2008) explored the relationship between transformational leadership behaviours, organizational justice and $\mathrm{OCB}$, and found a direct significant relationship between the variables. Further to this, Lo et al. (2006) investigated the role of equality of the leader-member exchange in promoting OCB and reported a significant relationship from a sample drawn from executives and managers in Malaysian manufacturing organizations. Othman et al. (2005) explored the relationship between psychological contract violation and $\mathrm{OCB}$, with justice perception as a moderator and reported partial support for the model. 


\section{Methodology and sample}

Using stratified random sampling, survey questionnaires were administered to fulltime management staff of a sample of 100 manufacturing companies selected from the 2,571 manufacturing companies listed in the Federation of Malaysian Manufacturers Directory. Questionnaires were distributed to ten management staff from each of the 100 companies. Overall 267 valid cases were used for the analysis. Of the 267 respondents, 56.6 percent are male and 43.4 percent are females. The majority of the respondents are aged between 25 and 40 years $(67.8 \%)$ and about two thirds $(66.3 \%)$ are married. More than half of the respondents have at least a Bachelor degree $(68.5 \%)$ and slightly more than a third are managerial staff (36.3\%). Half of the respondents are either engineers or executives (50.9\%). About half of the respondents $(48.3 \%)$ have been with their current organization for between three to ten years.

Primary data were collected from questionnaires written in English, which were sent by post to the selected companies. A cover letter and a postage-paid, return envelope for respondents to mail back the completed questionnaires were sent together with the questionnaire. The cover letter explained the purpose of the study, and emphasized the importance of responding to the questionnaire. Assurances of anonymity and confidentiality were also stated. Two weeks later, follow-up letters were mailed to non-respondents, stressing the value of the survey and the importance of their participation.

Items for all the constructs were measured using scales ranging from (1) strongly disagree to (5) strongly agree. Organizational justice was measured using 20 items taken from the scale developed Colquitt (2001). An example of a statement is "The procedures used to arrive at the (outcome) have been free of bias." The Cronbach alpha for each component was 0.888 for procedural justice, 0.866 for informational justice, 0.914 for distributive justice, and 0.868 for interpersonal justice. Job satisfaction was measured using five items from a scale developed by Brayfield and Rothe's (1951) and used by Price and Mueller (1986, $\alpha$ ranging from 0.78 to 0.99), Moorman (1991, $\alpha=0.86$ ) and Lambert et al. (2005, $\alpha=0.82$ ). The Cronbach alpha for this study was 0.865 . One of the items was "I am very satisfied with my job." OCB was measured using 24 items developed by Podsakoff et al. (1990) in which internal consistency reliabilities for the OCB scales ranged from 0.70 for civic virtue and 0.85 for altruism. The Cronbach alphas for the current study were 0.872 for courtesy, 0.871 for sportsmanship, 0.845 for altruism, 0.789 for civic virtue and 0.767 for conscientiousness. An example of an item was "I always help others who have heavy workloads." Eight questions tapped the demographic data of the respondents as well as some characteristics of the organizations.

After the removal of outliers, a factor analysis rotated with Varimax was conducted to examine the factor structure of the scales. With eigenvalues set at 1.00 , items with communalities more than 0.50 were retained. For justice measures, the items formed four factors representing procedural justice ( 7 items), informational justice (5 items), distributive justice (4 items) and interpersonal justice (4 items). For job satisfaction, only one factor was extracted, explaining 71.2 percent of the variance. One item was dropped due to low loading (JS5). For OCB variable, all five factors, namely courtesy 
(5 items), sportsmanship (5 items), altruism (5 items), civic virtue (4 items), and conscientiousness (4 items), were included to represent the construct. One item (Con1) was dropped due to low factor loading.

Correlation analysis was then conducted to describe the strength and direction of the linear relationship between the variables. Before analyzing the structural models, confirmatory factor analysis was conducted to test for convergent and discriminant validity of the constructs. Then, the final model was assessed using structural equation modeling with the AMOS 18 program to analyse its validity. To provide evidence of model fit, five fit indices have been identified for the study - Chi-Square $\left(\chi^{2}\right)$, Goodness-of-Fit Index (GFI), Tucker-Lewis Index (TLI), comparative fit index (CFI), and Root Mean Square Error of Approximation (RMSEA).

\section{Results}

\section{Measurement Model Analysis}

To assess the validity of the measure, all four justice factors were subjected to confirmatory factor analysis (CFA). The results of the first-order CFA indicated an acceptable fitting model with $\chi^{2}=382.388 ; \mathrm{p}<.001 ; \mathrm{GFI}=.877$; TLI $=.922$; CFI $=$ .932 ; and RMSEA $=.071$. All items that represented organizational justice were significantly loaded into their intended factors with standardized loadings of more than 0.50 . Theorganizational justice construct was then subjected to second-order CFA. The results revealed an acceptable fitting model with $\mathrm{y}^{2}=391.822 ; \mathrm{p}<.001 ; \mathrm{GFI}=.874$; $\mathrm{TLI}=.920 ; \mathrm{CFI}=.930 ;$ and RMSEA $=.072$. The standardized factor loadings for all the items were more than 0.50 and were significantly loaded into their intended factors, indicating convergent validity.

Results of the first-order CFA for OCB signified an acceptable fitting model with $\mathrm{y}^{2}=$ 499.025; $\mathrm{p}<.001 ; \mathrm{GFI}=.862 ; \mathrm{TLI}=.889 ; \mathrm{CFI}=.903 ;$ and RMSEA $=.069$. Standardized factor loadings for all items ranged from 0.599 to 0.836 , and, therefore, no items were dropped. Second-order confirmatory factor analysis carried out implied an acceptable fitting model with $\mathrm{y}^{2}=520.290 ; \mathrm{p}<.05$; GFI $=.855$; TLI $=.885$; CFI $=$ .898 ; and RMSEA $=.070$. Except for sportsmanship, standardized factor loadings for all the other items were above 0.50 , thus, confirming convergent validity.

The results of the goodness of fit indices indicated a well-fitting measurement model with $\mathrm{y}^{2}=150.565 ; \mathrm{p}<.05 ;$ GFI $=0.916$; TLI $=0.915 ; \mathrm{CFI}=0.932$; and RMSEA $=$ 0.073 . The standardized regression weights showed that except for sportsmanship, all the items were significantly loaded into the intended factor with standard loadings ranging from 0.591 to 0.841 . There was no empirical or theoretical justification to modify or re-specify any of the existing relationships in the hypothesized model. The CFA results confirmed that the theoretical measurement model was valid.

To measure discriminant validity, a Chi square difference test was performed on the nested models. Four models that were specified provided evidence for discriminant validity. First, the three-construct model was specified where all constructs organizational justice, job satisfaction and organizational citizenship behaviour were treated as independent variables. Then, a two-construct model in which job satisfaction and organizational citizenship behaviour were loaded into one construct 
was specified. Finally, only one latent construct model was specified in which all 13 measured items were indicators. Each model was tested and its fit compared to the fit of the original three-construct model. As shown in Table 2, the model fits were significantly different, suggesting that the 13 items represent three separate constructs. Significant Chi square differences $\left(\Delta \mathrm{y}^{2}>3.84\right.$ for $\left.\mathrm{df}=1\right)$ were observed in all cases, thus, providing evidence of discriminant validity. In essence, the model has fulfilled the criterion of distinctiveness. Having confirmed the adequacy of the measurement model, subsequent testing in the structural form was possible (Table 1).

Table 1: CFA Comparison of the Measurement Models

\begin{tabular}{|lllll|l|l|r|}
\hline Model & $\chi^{\mathbf{2}}$ & df & GFI & TLI & & CFI & RMSEA \\
\hline 3-Factor Model & 150.565 & 62 & 0.916 & 0.915 & & 0.932 & 0.073 \\
2-Factor Model & 339.764 & 64 & 0.806 & 0.743 & & 0.789 & 0.127 \\
1-Factor Model & 433.349 & 65 & 0.767 & 0.662 & & 0.718 & 0.146 \\
\hline
\end{tabular}

Source: own research

\section{Summary of findings on hypothesized relationships}

\section{Hypothesis 1: Organizational Justice - Organizational Citizenship Behaviour} Relationship

As summarized in Table 2, the hypothesis relating employee perceptions of organizational justice to the dimensions of OCB was partially supported.

Table 2: Organizational Justice - Organizational Citizenship Behaviour

\begin{tabular}{|c|c|c|c|c|}
\hline Factors/Items & Std. Loading & S.E. & C.R. & $\mathbf{P}$ \\
\hline Courtesy $\leftarrow$ Procedural justice & -0.128 & 0.051 & -1.988 & 0.047 \\
\hline Sportsmanship $\leftarrow$ Procedural justice & -0.136 & 0.076 & -2.007 & 0.045 \\
\hline Altruism $\leftarrow$ Procedural justice & 0.101 & 0.054 & 1.497 & 0.134 \\
\hline Civic virtue $\leftarrow$ Procedural justice & 0.170 & 0.060 & 2.382 & 0.017 \\
\hline Conscientiousness $\leftarrow$ Procedural justice & -0.069 & 0.058 & -1.036 & 0.300 \\
\hline Courtesy $\leftarrow$ Informational justice & 0.177 & 0.071 & 2.656 & 0.008 \\
\hline Sportsmanship $\leftarrow$ Informational justice & 0.082 & 0.103 & 1.208 & 0.227 \\
\hline Altruism $\leftarrow$ Informational justice & 0.072 & 0.074 & 1.067 & 0.286 \\
\hline Civic virtue $\leftarrow$ Informational justice & -0.022 & 0.080 & -0.311 & 0.756 \\
\hline Conscientiousness $\leftarrow$ Informational justice & 0.045 & 0.079 & 0.675 & 0.500 \\
\hline Courtesy $\leftarrow$ Distributive justice & -0.029 & 0.043 & -0.467 & 0.640 \\
\hline Sportsmanship $\leftarrow$ Distributive justice & -0.113 & 0.064 & -1.705 & 0.088 \\
\hline Altruism $\leftarrow$ Distributive justice & -0.046 & 0.046 & -0.699 & 0.485 \\
\hline Civic virtue $\leftarrow$ Distributive justice & 0.153 & 0.051 & 2.207 & $\mathbf{0 . 0 2 7}$ \\
\hline Conscientiousness $\leftarrow$ Distributive justice & -0.109 & 0.050 & -1.647 & 0.100 \\
\hline Courtesy $\leftarrow$ Interpersonal justice & 0.389 & 0.077 & 5.206 & $* * *$ \\
\hline Sportsmanship $\leftarrow$ Interpersonal justice & 0.191 & 0.102 & 2.750 & 0.006 \\
\hline Altruism $\leftarrow$ Interpersonal justice & 0.334 & 0.082 & 4.324 & $* * *$ \\
\hline Civic virtue $\leftarrow$ Interpersonal justice & 0.327 & 0.087 & 4.183 & $* * *$ \\
\hline Conscientiousness $\leftarrow$ Interpersonal justice & 0.480 & 0.097 & 5.608 & $* * *$ \\
\hline
\end{tabular}

Source: own research

Distributive justice positively influenced civic virtue whilst informational justice had a significant positive effect on courtesy. Procedural justice positively influenced civic virtue, but had a negative effect on courtesy and sportsmanship. Employee perceptions of interpersonal justice, however, positively influenced all dimensions of OCB. 
Comparatively, interpersonal justice had a more significant effect on conscientiousness than on courtesy, altruism, civic virtue, or sportsmanship. The influence of interpersonal justice on civic virtue was stronger than the effect of procedural justice or distributive justice. Similarly, interpersonal justice was more significant on courtesy as compared to informational justice or procedural justice. Comparatively, interpersonal justice had a stronger influence on sportsmanship than procedural justice. Hypothesis 2: Organizational Justice - Job Satisfaction Relationship

As evidenced in Table 3, employee perceptions of organizational justice positively influenced job satisfaction. All dimensions of organizational justice were significantly related to job satisfaction. Among the justice factors, informational justice had a greater influence on job satisfaction than distributive justice, procedural justice, or interpersonal justice. Therefore, the hypothesis that employee perceptions of organizational justice positively influence job satisfaction was supported.

Table 3: Results on Organizational Justice - Job Satisfaction Relationship

\begin{tabular}{|c|c|c|c|c|}
\hline Factors/Items & Std. Loading & S.E. & C.R. & $\mathbf{P}$ \\
\hline Job satisfaction $\leftarrow$ Procedural justice & 0.229 & 0.065 & 3.460 & **** \\
\hline Job satisfaction $\leftarrow$ Informational justice & 0.334 & 0.096 & 4.652 & **** \\
\hline Job satisfaction $\leftarrow$ Distributive justice & 0.273 & 0.056 & 4.203 & $* * *$ \\
\hline Job satisfaction $\leftarrow$ Interpersonal justice & 0.159 & 0.084 & 2.438 & 0.015 \\
\hline
\end{tabular}

Source: own research

\section{Hypothesis 3: Job Satisfaction-Organizational Citizenship Behaviour Relationship}

As evidenced in Table 4, job satisfaction positively influenced all dimensions of OCB. Thus, the hypothesis that job satisfaction positively influence OCB was substantiated. The effect of job satisfaction on organizational citizenship behaviour was most significant on civic virtue, followed by courtesy, altruism, conscientiousness, and sportsmanship.

Table 4: Job Satisfactions - Organizational Citizenship Behaviour Relationship

\begin{tabular}{|c|c|c|c|c|}
\hline Factors/Items & Std. Loadin g & S.E. & C.R. & $\mathbf{P}$ \\
\hline Courtesy $\leftarrow$ Job Satisfaction & 0.428 & 0.052 & 5.883 & $* * *$ \\
\hline Sportsmanship $\leftarrow$ Job Satisfaction & 0.155 & 0.070 & 2.215 & 0.027 \\
\hline Altruism $\leftarrow$ Job Satisfaction & 0.404 & 0.057 & 5.269 & \\
\hline Civic virtue $\leftarrow$ Job Satisfaction & 0.511 & 0.064 & 6.376 & $* * *$ \\
\hline Conscientiousness $\leftarrow$ Job Satisfaction & 0.396 & 0.059 & 4.943 & \\
\hline
\end{tabular}

Source: own research

Hypothesis 4: The Role of Job Satisfaction in the Justice-Citizenship Relationship

The possibility that the relationship between organizational justice and OCB was mediated by job satisfaction was analysed using a two-step process. At Step 1, the significant relationships between the constructs were established. For this, the correlations between constructs in the CFA model shown in Table 5 was referred. From the analysis of the correlations that were obtained after standardization, the interconstruct correlations were significant for all the four constructs. As shown in Table 5, organizational justice was significantly related to OCB (0.409), ensuring that 
the direct, unmediated relationship was significant. Organizational justice was also significantly related to job satisfaction (0.721) establishing relationship with the potential mediator. Finally, OCB was significantly related to job satisfaction (0.426), thus, supporting relationships between the mediator and the outcome variable.

Table 5: Construct Correlation Matrix (Standardized)

\begin{tabular}{|c|c|c|c|}
\hline & OJ & JS & OCB \\
\hline $\mathrm{OJ}$ & 1.000 & 0.520 & 0.167 \\
\hline JS & $0.721 * * *$ & 1.000 & 0.181 \\
\hline$\overline{\mathrm{OCB}}$ & $0.409 * * *$ & $0.426 * * *$ & 1.000 \\
\hline
\end{tabular}

Significance Level: $*=0.05, * *=0.01, * * *=0.001$

Note: Values below the diagonal are correlation estimates among constructs, diagonal elements are construct variances, and values above the diagonal are squared correlations

Source: own research

Step 2 was to estimate the mediated model and assess the level of mediation. First, was to estimate the original model, which did not estimate the direct effect from organizational justice to OCB. Then, a revised model, with the added direct path between organizational justice and OCB was estimated. This was to assess if adding the direct effect would substantially change the model fit. The results in Table 6 showed that the revised model with the direct relationship had a slight decrease in Chi square $\left(\Delta \chi^{2}=3.024, \mathrm{df}=1, \mathrm{p}=0.000\right)$ and an insignificant path estimate for the organizational justice-OCB relationship. These indicated that there was complete mediation, that is, the existence of a fully mediated model. In the revised model, the path estimate between organizational justice (OJ) and the mediator (JS) was still significant. Job satisfaction still had a significant relationship with OCB (JS -, OCB is significant) at 0.05 significant level $(\mathrm{p}=0.02)$. As OJ -, JS -, OCB contained paths that were all significant, and the OJ -, OCB path estimate was not significant, the model supported full mediation.

Table 6: Testing for Mediation in the Justice-Citizenship Model

\begin{tabular}{|c|c|c|}
\hline Model Element & Original Model & Revised Model \\
\hline \multicolumn{3}{|l|}{ Model Fit } \\
\hline Chi square $\left(\chi^{2)}\right.$ & 153.589 & 150.565 \\
\hline Degrees of freedom & 63 & 62 \\
\hline Probability & 0.000 & 0.000 \\
\hline CMINDF & 2.438 & 2.428 \\
\hline RMSEA & 0.074 & 0.073 \\
\hline CFI & 0.931 & 0.932 \\
\hline \multicolumn{3}{|c|}{ Standardized parameter estimates } \\
\hline 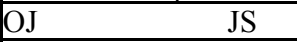 & $0.727 * * *$ & $0.721 * * *$ \\
\hline $\mathrm{OCB}$ & $0.438 * * *$ & $0.272 *$ \\
\hline $\mathrm{OJ}$ & 0.000 & 0.213 \\
\hline
\end{tabular}

Source: own research

The magnitude of the mediating effect was demonstrated by breaking down the total effects into direct and indirect effects. A breakdown of the effects of OJ -, OCB both in the original model (no direct effects from OJ -, OCB) and the revised model (direct effect added for OJ -, OCB) is shown in Table 7. In the original model, 
substantial indirect effects were present, thus, supporting the presence of mediating effect of job satisfaction. Although the indirect effects decreased, the insignificant direct effect made this a full mediation situation.

Table 7: Assessing Direct and Indirect Effects in a Mediated Model

\begin{tabular}{ccc} 
Effects of $\mathbf{O J} \rightarrow$ OCB & $\begin{array}{c}\text { Original ModelRevised Model } \\
\text { (Only Indirect Effects)(Indirect and Direct Effects) }\end{array}$ \\
\hline Total effects & 0.319 & 0.409 \\
Direct effects & 0.000 & 0.213 \\
Indirect effects & 0.319 & 0.196
\end{tabular}

Source: own research

The results of the mediated relationship implied that job satisfaction fully mediated the relationship between organizational justice and OCB. In short, organizational justice had no direct effect on OCB, but was fully mediated by job satisfaction. Therefore, the hypothesis that job satisfaction mediates the relationship between organizational justice and OCB was supported.

\section{Discussion}

\section{Organizational Justice-Organizational Citizenship Behaviour Relationship}

The findings of the study affirm that there is indeed a positive relationship between organizational justice and OCB, albeit partially. The findings establish the strong influence of interactional justice, in particular, interpersonal justice on OCB. To a certain extent, the findings support the assertion that interactional justice is the sole dimension of fairness to significantly relate to OCB (Lazar et al., 2007; Moorman, 1991). It is, therefore, crucial that organizations ensure politeness and treat employees with respect and dignity (Colquitt, 2001) as employees are more willing to accept unfavorable outcomes (Deutsch, 2000).

Besides, only interpersonal justice relates significantly to sportsmanship. In short, employee perceptions of justice do not necessary encourage avoidance of negative behaviours and complaints. Employees avoid negative behaviours only if superiors treat them with respect and dignity. Equity in the distribution of outcomes, objectivity in decision procedures, as well as adequate and honest explanations do not deter pessimistic behaviours. To avoid negative behaviours from escalating, it is desirable that organizations provide adequate training to enhance interpersonal skills of superiors. Enhanced interpersonal skills improve social relations among employees and mitigates misunderstanding and conflict at the workplace. Additionally, organizations benefit from activities that promote workplace harmony, as such activities foster team work and increase employee morale. Well established grievance procedures are also likely to improve sportsmanship at the workplace.

Furthermore, the results establish that interactional justice has a significant effect on courtesy, but only interpersonal justice significantly affects the other dimensions of OCB. The association between interpersonal justice and altruism supports the findings of Giap et al. (2005) which affirm that employees do extra-role work to help when their supervisors treat them respectfully; akin to Organ's (1997) contention that employees contain extra-role behaviour if employees perceive injustice. Similarly, 
Sweeney and McFarlin (1993) assert that employee perceptions of injustice restrict employee willingness to help other employees. Informational justice enhances employees' obligation of cooperation with others and has no significant effect on other dimensions of OCB.

However, the current findings dispute prior studies that contend that procedural justice is an important determinant of OCB (e.g. Farh et al., 1990; Moorman, 1991; Tansky, 1993). The current findings are also incongruent with the findings of Nadiri and Tanova (2010) where distributive justice is a stronger predictor of OCB and that distributive justice is associated with altruism and conscientiousness (Organ and Konovsky, 1989). It further differs from meta-analytic data that show positive correlations between both procedural and distributive justice and OCB (Colquitt et al., 2001; Giap et al., 2005). The current study suggests that perceived fairness of interpersonal treatment by managers as well as adequate and sincere communication of procedures and outcomes rather than fairness of a firm's procedures would have a stronger impact on OCB. Based on the current study, to enhance OCB, managers may have to make a concerted effort to treat employees with greater respect and dignity.

In the current study, employee perceptions of procedural justice relate negatively to courtesy and sportsmanship. Hence, the results challenge prior research that contend the linear relationship between procedural justice and altruism (Farh et al., 1990); and altruism, courtesy, sportsmanship, and conscientiousness (Moorman, 1991). The inverse correlation indicates that employees have a tendency of containing cooperative behaviours and complain more if procedures in decision outcomes are perceived as fair. In essence, perceptions of procedural justice reduce employees' efforts in avoiding negative behaviours and not complaining in case of problems. Concisely, employees are less tolerant and tend to behave negatively when equity in decision outcome procedures exists. Additionally, procedural justice hinders helpful behaviours, as well as discourages team working and collaboration among employees. Such attitudes may be detrimental to organizations, as collaboration and consultation are sometimes instrumental in mitigating the severity of a foreseen problem.

The current study ascertains that distributive, procedural, and interpersonal justice, positively influence civic virtue. This confirms the findings of Robinson and Morrison (1995) that employee perceptions of fairness enhance civic behaviour. This indicates that organizational justice is a key determinant of whether employees take an interest in company affairs and developments, and make efforts that promote self as well as organization interest. Succinctly, organizational justice is a strong determinant of whether employees respond appropriately and responsibly to the political life of the organization. Fair procedures encourage employees to stay up-to-date with important issues of the organization and support the needs of the group (Moorman and Blakely, 1995). Awareness of happenings at the workplace not only helps employees respond quickly, but also promotes citizenship behaviours in the long run.

\section{Organizational Justice-Job Satisfaction Relationship}

The results of the study show that all dimensions of organizational justice positively influence job satisfaction. Informational justice has the most significant influence 
followed by distributive justice, procedural justice, and interpersonal justice. This is consistent with prior research that affirm the relationship between fairness and job. Specifically, distributive justice and procedural justice are related to job satisfaction (Colquitt et al., 2001; Lee et al., 2000; Sweeney and McFarlin, 1993) while interactional justice has a significant impact on both job satisfaction (Azman, et al., 2011; Colquitt, et al., 2001) and performance (Fernandes and Awamleh, 2006). Employees' perception of equity in distribution enhances employees' satisfaction with supervisors (Schaubroeck et al., 1994; Sweeney and McFarlin, 1993). Others concur that only procedural fairness enhances job satisfaction (Igbaria and Greenhouse, 1992). Nonetheless, the current study disagrees with other studies that indicate that procedural justice rather than distributive justice is more strongly related to job satisfaction (Hassan, 2011; Schaubroeck et al., 1994). In this study, distributive justice rather than procedural justice is a stronger predictor of job satisfaction.

The importance of informational justice among justice factors in enhancing job satisfaction suggests that organizational decisions are not perceived as transparent and impartial. If honest and adequate explanations for decisions were given, employees are unlikely to perceive informational justice as the key determinant of job satisfaction. As job satisfaction affects other organizational phenomena that may have an impact on organizational performance, it is of paramount significance that organizations ensure transparency in decisions. Employees tend to lose confidence in ambiguous and partial decisions that affect their career and tenure with the organization. Being in a high power distance environment, employees are unlikely to openly confront disputable decisions. Enduring in silence would probably aggravate employee feelings of discontentment and may result in unfavourable outcomes for the organizations. Therefore, organizations would probably benefit from investing in developing decision makers to effectively articulate organizational decisions. Alternatively, organizations can involve employees in decision making as participation in decision-making is likely to instill OCB. Opportunity to participate in decision-making enhances employees' perceptions of procedural justice (Organ, 1988a; Thibaut and Walker, 1975) and promotes social exchange relationships between employees and their supervisors (Organ,1988a). Based on the norm of reciprocity (Gouldener, 1960), employees are likely to reciprocate by exhibiting OCB (Organ, 1988a).

In contrast to prior studies, distributive justice rather than procedural justice has a more significant influence on job satisfaction. This suggests that employees are concerned about fairness in decision outcomes. Organisations, therefore, have to reward accordingly (Homans, 1961), and ensure that outcomes adhere to expectations (Blau, 1964). Employees are less concern with the fairness in procedures in the decision making process. As long as outcomes are consistent with implicit norms for allocation (Colquitt, 2001), employees experience job satisfaction. The results imply that employees in general tend to be materialistic. Regardless of the procedures involved, equality of outcomes is of prime concern. A lack of perceived fairness in procedures probably will not affect job satisfaction if employees perceive that rewards are contingent on the level of contribution (Yilmaz and Tazdan, 2009). Hence, organizations may have to focus on improving distributive justice to enhance job satisfaction. 
Interpersonal justice has the least effect on job satisfaction. Employees do not seem concerned with respectful treatment from their superiors. As long as explanations in decision procedures are honest and adequate; outcomes received meet expectations; and procedures in decision outcomes are fair, employees experience job satisfaction. On one hand, the indifferent attitude of employees towards the authorities implies that the superior-subordinate relationship in the organizations may not be strong. On the other hand, high interpersonal justice probably exists at the workplace, and, therefore, the impact on job satisfaction is not strong. Organizations in the former situation may have to work on strengthening the bond between superior and subordinates, and improving employee interest in the organization to foster greater employee commitment. In the latter case, organizations would probably benefit from improving other justice factors to enhance work performance.

\section{Job satisfaction-organizational citizenship behaviour relationship}

The hypothesis that job satisfaction positively influences the dimensions of OCB is supported. In order of importance, job satisfaction, has a significant effect on civic virtue, courtesy, conscientiousness, altruism, and sportsmanship. The findings support empirical studies that show a significant association between job satisfaction and some dimensions of OCB (e.g. Bateman and Organ, 1983; Foote and Tang, 2008; Murphy et al., 2002; Tansky, 1993). Smith et al. (1983) affirm the influence of job satisfaction on altruism and conscientiousness while Williams and Anderson (1991) emphasize the effect on conscientiousness. The current study, on the contrary, shows a stronger correlation between job satisfaction and civic virtue, and courtesy. In essence, job satisfaction increases employee interest to participate appropriately and responsibly in company matters to enhance corporate governance. Proactive, responsible participation in the political life of the organization improves employee awareness of the affairs and developments at the workplace. Employees are likely to go for self-improvement to enhance competencies to stay up-to-date with important issues of the organization.

Results of the study further emphasize the importance of job satisfaction on courtesy. As courtesy concerns undertaking and carrying out the obligation of cooperation with others, increased job satisfaction would probably enhance team working, create a more disciplined and committed workforce, and improve behaviours and attitude at the workplace. As these worker attitudes and behaviours enhance productivity, creativity, innovation, performance, and openness to change (Mathieu and Zajac, 1990), it would be beneficial for organizations to improve job satisfaction. Such supportive behaviours encourage communication and collaboration at the workplace to alleviate the intensity of job-related problems. Besides, it promotes social interaction, mutual understanding, team spirit, and harmony at the workplace. Problems of diversity at the workplace which could escalate into discrimination, harassment, hostility, conflicts, and social alienation could be better managed.

As job satisfaction has a significant effect on conscientiousness, organizations would profit from leveraging employee conscientiousness for achieving organizational goals. For organizational effectiveness, employees' sincere devotion to the organization and respect for company policies beyond the organization's requirements (Eskew, 1993; 
Tansky, 1993) is fundamental. Organizational effectiveness is essential for sustainability, and the importance of positive work behaviours is indisputable. Therefore, measures to ensure that employees contribute beyond roles specified in the job description are crucial. Introducing incentive programs to reward employees that adhere to organizational rules, procedures, and regulations is a way to motivate employees to display characteristics of conscientiousness. Considering the damaging consequences of negative work behaviours, it may be worthwhile for organizations to invest in grooming conscientious workers. Conscientious workers naturally are role models to be exemplified and could be a source of motivation for other employees. A motivated and productive workforce would translate to better quality of goods, which in turn would enhance not only job satisfaction, but also customer satisfaction and loyalty.

Since job satisfaction also influences altruism, improving job satisfaction becomes increasing important. Organizations stand to gain if altruism is present at the workplace, as productivity and performance are likely to improve. The voluntary behaviour of helping co-workers in the organization in work-related matters not only promotes prosocial, helpful behaviours and neighbourliness among employees, but also expedite completion of work-related tasks. Such discretionary behaviours have positive effects for the organization, and may even be instrumental for a company's survival. To avoid distracting and showing supervisors their lack of competence, employees may engage in knowledge sharing. Employees reap benefits from both knowledge donation and knowledge collection, which may in turn inspire them to further acquire new knowledge. A knowledgeable workforce in a learning organization is valuable for gaining competitive advantage in an uncertain, challenging global environment.

Thus, it would be advantageous for organizations to improve job satisfaction to garner the benefits of OCB. Enhancing job satisfaction may entail increasing salaries and improving working conditions (Nadiri and Tanova, 2010). Flexitime and working remotely may also enhance job satisfaction. Increased job satisfaction together with effective training has the potential to contribute significantly to the bottom line of any organization. Furthermore, as job dissatisfaction causes anxiety (Spector et al., 1988), depression (Bluen et al., 1990), lower affective organizational commitment (Meyer et al., 2002), poorer in-role performance (Judge et al., 2001), and contextual performance (Podsakoff et al., 2000), ignoring job satisfaction may be detrimental to organizational effectiveness. Therefore, it is recommended that organizations implement policies and practices that augment job satisfaction. Job satisfaction is of utmost importance as it is significantly related to all dimensions of OCB. Organizations may have to focus on job satisfaction to enhance OCB.

\section{The role of job satisfaction in the justice-citizenship relationship}

It is hypothesized that job satisfaction and leader-member exchange mediate the relationship between organizational justice and OCB. The findings reveal full mediation for job satisfaction, and therefore, hypothesis 4 is substantiated. However, this contradicts extant literature that asserts that employee perceptions of fairness, and not job satisfaction is the main determinant of OCB if job satisfaction and perceptions of fairness were both measured (Moorman, 1991; Nadiri and Tanova, 2010; Organ, 
1988b, 1990). Organ (1988b, 1990) further reiterates that the relationship between job satisfaction and OCB probably reflects employee perceptions of organizational justice. Nadiri and Tanova (2010) contend that though employees may be satisfied, employees will not demonstrate OCBs if employees do not perceive organizational justice. Tension escalates in response to perceive injustice, and this translates into lower citizenship behaviours. Moreover, employees that favor social exchange are more likely to demonstrate OCBs if equity exists. Despite the importance of organizational justice rather than job satisfaction in determining OCBs, the current study shows that job satisfaction is a more significant predictor.

Full mediating effect of job satisfaction in the organizational justice-OCB relationship demonstrates that job satisfaction is indeed an important predictor. Thus, in contrast, organizational justice may not be as significant on OCB as expounded in prior studies. This implies that practitioners should aim to improve OCB through improved job satisfaction. The effect on OCB would be minimal if practitioners were to focus on improving organizational justice. Increased job satisfaction would probably enhance morale, motivation, and team working; create a more disciplined and committed workforce; and improve behaviours and attitude at the workplace. These would likely engage employees in civic behaviour, generating renewed interest in happenings in the organization. Employees' concern and attention in organizational affairs augments OCB. The results of the study suggest that organizations need to pay more attention to programs and policies that encourage job satisfaction if OCB is the priority of management. Nonetheless, organizations need to focus on overall justice to enhance job satisfaction, and hence, OCB. As organizational justice has a significant influence on job satisfaction, it is crucial for organizations to manage fairness effectively to enhance OCB. The current study shows that the relationship between organizational justice and job satisfaction is more significant than the organizational justice-OCB relationship. To further justify the need to improve overall justice, the study concurs with the assertion that positive justice perceptions possibly reinforce affirmative citizenship perceptions, and, therefore, the more robust organizational citizenship perceptions are, the more positive the organizational justice perception will be (Yilmaz and Tasdan, 2009).

\section{Managerial implications and contributions}

From a practical perspective, this study has important implications for managers and organizations. Of utmost significance is the indication of the importance of each justice factors on job satisfaction and the dimensions of OCB. This is useful for managers to monitor a wide range of employee behaviours that may be detrimental to organizational effectiveness. The current findings reveal explicitly which justice factor to focus on to enhance job satisfaction, and each dimension of OCB. Previous studies have offered one-dimensional analysis of the effect of organizational justice on job satisfaction and OCB (e.g. Yilmaz and Tasdan, 2009) and job satisfaction on OCB (e.g. Murphy et al., 2002. Other studies have researched perceived organizational justice and OCBs separately (e.g. Skarlicki and Folger, 1997). However, knowing how each independent construct affects the dimensions of OCB helps diagnose opportunities for intervention and improvement to enhance OCB in the workplace. 
Though managers may have little direct control over some employee attitudes and behaviours, the findings suggest that managers can increase OCB, in particular courtesy, through demonstrating interactional justice. By treating employees with dignity and respect, OCB is expected to improve as it affects all dimensions of OCB. As workplace success among other factors depends on respect for people, the findings support that interpersonal justice is indeed important. The way managers treat employees has a significant influence on their attitudes and commitment and, as a consequence, on their performance. Employees generally are more likely to response affirmatively to meet the demands of increased workload if there is perceived equity. Greenberg (1988) contends that actively communicating fairness through interaction rather than merely relying on actual fair behaviour has greater success of improving perceptions of fairness. The findings propose that if managers practice effective and fair communication, there is a probability that OCB would improve. Enhancing informational justice does not cost an organization much, but the absence of it may be a costly affair. The implementation of informational justice is feasible if organizations were to invest in enhancing communication skills of managers to improve perceive fairness in decision-making. Besides, fair personal treatment in decision-making processes is likely to augment affirmative employee behaviours. Therefore, prompt and honest feedback is essential to maintain trust and confidence in managerial decisions. As perception of justice is formed quickly, inadequate information in decision-making may influence the perception of subsequent actions (Klendauer and Deller, 2009). Indubitably, it is of paramount importance that organizations convince employees about management sincerity in ensuring equity in information sharing. Strategic manipulation intentions may generate counterproductive effects (Klendauer and Deller, 2009) that can spiral beyond managerial control.

Moreover, providing adequate explanations for decisions and events that affect them improve job satisfaction. As job satisfaction has a significant influence on all dimensions of OCB, improving job satisfaction is likely to enhance OCB. As "happy" employees are "productive" employees (Katzell and Yankelovich, 1975), it would be beneficial for managers to promote OCB to influence employees to enhance commitment and performance. Intuitively, identification with the organization would reduce employee alienation and enhance collaboration at the workplace. Employees are more likely to cooperate to help achieve organizational goals, devote sincerely to the organization, avoid disapproving behaviours, and increase interest in organizational affairs. These traits are instrumental for gaining competitive advantage in the face of current global challenges.

These findings suggest that organizational justice may have a greater impact on OCB via job satisfaction when compared to the direct effect of organizational justice on OCB. Organizational justice has long been thought to lead to improved OCB, but the results of this study indicate that organizational justice may not play a significant role in enhancing OCB. On the contrary, enhancing job satisfaction may produce better results. Therefore, if organizations were to increase $\mathrm{OCB}$, the focus would be on improving job satisfaction rather than organizational justice. To improve job satisfaction, managers would probably have to focus on providing adequate and honest explanations for decision outcomes. Organizational leaders may improve employee 
perceptions of justice by providing timely information, ensuring equity in distribution of outcomes, enacting fair procedures, and treating subordinates with dignity and respect.

Consequently, the need for organizations to train and educate their managers on the impact of the perceived lack of justice on job satisfaction and OCB is inevitable. In the current era of globalization, increased diversity at the workplace provides more challenges for organizations. A diverse workforce may influence employee perceptions of justice and what used to be the norm at the workplace may no longer be acceptable. Moreover, technological advancement has enable employees to communicate globally, thus, enhancing awareness of global opportunities which may entice employees to leave. Besides, sharing knowledge globally creates awareness on employee rights, and perceived injustice may lead to dissatisfaction, and hence, lower OCB. In essence, appropriate training to enhance managerial competences in ensuring organizational justice is crucial for improving OCB.

\section{Conclusion}

This study presented an integrated analysis of the organizational justice-OCB relationship by including job satisfaction as a mediator to provide a wholesome perspective of the associations between organizational justice and OCB. The study has expounded on the importance of job satisfaction in the organizational justice-OCB relationship, and therefore, the correlation between these constructs must not be overlooked. Practitioners may have to focus on job satisfaction to enhance OCB. Increased job satisfaction together with effective training to improve managerial competence in decision making would likely increase OCBs which ultimately results in better performance. Therefore, organizations would have to improve organizational justice in tandem with job satisfaction to enhance OCB. Among justice factors, interactional justice is important in influencing $\mathrm{OCB}$, in particular interpersonal justice. Concisely, the findings indicate that personal factors are imperative for advancing OCBs.

\section{References}

1. Asgari, A., Silong, A.D., Ahmad, A., Abu Samah, B. (2008): The relationship between transformational leadership behaviours, organizational justice, leader-member exchange, perceived organizational support, trust in management and organizational citizenship behaviours. European Journal of Scientific Research 23(2): 227242.

2. Azman, I., Mohamed, H.A., Hamid, N.S., Sulaiman, A.Z., Girardi, A. Abdullah, M.M. (2011): Relationship between performance based pay, interactional justice and job satisfaction: A mediating model approach. International Journal of Business and Management 6(11): 170-180.

3. Bateman, T.S., Organ, D.W. (1983): Job satisfaction and the good soldier: The relationship between affect and employee citizenship. Academy of Management Journal 26(4): 587-595.

4. Blau, P. (1964): Exchange and Power in Social Life. New York: Wiley.

5. Bluen, S.D., Barling, J., Burns, W. (1990) Predicting sales performance, job satisfaction, and depression by using the achievement strivings and impatience-irritability dimensions of Type A behaviour. Journal of Applied Psychology 75(2): 212-216.

6. Brayfield, A.H., Rothe, H.F. (1951): An index of job satisfaction. Journal of Applied Psychology 35(5): 307311. 
7. Colquitt, J.A., Conlon, D.E. Wesson, M.J., Porter, C.O.L.H., Ng, K.Y. (2001): Justice at the millennium: A meta-analytic review of 25 years of organizational justice research. Journal of Applied Psychology 86(3): 425445.

8. Colquitt, J.A. (2001): On the dimensionality of organizational justice: A construct validation of a measure. Journal of Applied Psychology 86(3): 386-400.

9. DeConinck, J.B. (2010): The effect of organizational justice, perceived organizational support, and perceived supervisor support on marketing employees' level of trust. Journal of Business Research 63(12): 1349-1355.

10. Deutsch, M. (2000): Justice and conflict. In: M. Deutsch and P.T. Coleman (eds.), The Handbook of Conflict Resolution: Theory and Practice. San Francisco, CA: Jossey Bass.

11. Eskew, D.E. (1993): The role of organizational justice in organizational citizenship behaviour. Employee Responsibilities and Rights Journal 6(3): 185-194.

12. Farh, J., Podsakoff, P.M. and Organ, D.W. (1990): Accounting for organizational citizenship behaviour: Leader fairness and task scope versus satisfaction. Journal of Management 16(4): 705-721.

13. Fassina, N. E., Jones, D. A., Uggerslev, K. L. (2008): Relationship clean-up time: Using meta analysis and path analysis to clarify relationships among job satisfaction, perceived fairness, and citizenship behaviours. Journal of Management 34(2): 161-188.

14. Fernandes, C., Awamleh, R. (2006): Impact of organizational justice in an expatriate work environment. Management Research News 29(11): 701-712.

15. Foote, D.A., Tang, T.L. (2008): Job satisfaction and organizational citizenship behaviour (OCB): Does team commitment make a difference in self-directed teams? Management Decision 46(6): 933-947.

16. Giap, B.N., Hackermeier, I., Jiao, X., Wagdarikar, S.P. (2005): Organizational citizenship behaviour and perception of organizational justice in student jobs. Research Study, Psychology of Excellence Instructional Design, Job Analysis and Job Design, 04 July 2005.

17. Greenberg, J. (1988): Cultivating an image of justice: Looking fair on the job. Academy of Management Executive 2(2): 155-157.

18. Hassan, A., Al Jubari, I.H.A. (2010): Organizational justice and employee work engagement: LMX as mediator. Journal of International Business and Entrepreneurship Development 5(2): 167-178.

19. Hassan, A., Hashim, J. (2011): Role of organizational justice in determining work outcomes of national and expatriate academic staff in Malaysia. International Journal of Commerce and Management 21(1): 82-93.

20. Hassan, A., Mohd Noor, K. (2008): Organizational justice and extra-role behaviour: Examining the relationship in the Malaysian cultural context. IIUM Journal of Economics and Management 16(2): 187-208.

21. Homans, G.C. (1961): Social Behaviour: Its Elementary Forms. London: Routledge and Kegan Paul.

22. Hooi, L.W. (2011): The role of leader-member exchange in organizational justiceorganizational citizenship behaviour relationship, Research and Practice in Human Resource Management 19(2): 71-91.

23. Ishak, N.A., Alam, S.S. (2009): The effects of leader-member exchange on organizational justice and organizational citizenship behaviour: Empirical study. European Journal of Social Sciences 8(2): 324-334.

24. Ismail, M.T., Abdul Karim, S.A, Alwadi, S. (2011): A study of structural breaks in Malaysian stock market. African Journal of Business Management 5(6): 2418-2425.

25. Judge,T.A., Thoresen, C.J., Bono, J.E., Patton, G.K. (2001): The job satisfaction-job performance relationship: A qualitative and quantitative review. Psychological Bulletin 127(3): 376-407. 
26. Katzell, R. A., Yankelovich, D. (1975): Work, Productivity, and Job Satisfaction. New York: Psychological Corp.

27. Khalid, S., Ali, H. (2005): The effect of organizational citizenship behaviour on withdrawal behaviour: A Malaysian Study. International Journal of Management and Entrepreneurship 1(1): 30-40.

28. Klendauer, R., Deller, J. (2009): Organizational justice and managerial commitment in corporate mergers. Journal of Managerial Psychology 24(1): 29-45.

29. Lambert, E.G., Cluse-Tolar, T., Pasupuleti, S., Hall, D.E., Jenkins, M. (2005): The impact of distributive justice and procedural justice on social service workers. Social Justice Research 18(4): 411-427.

30. Latham, G., Pinder C. (2005): Work motivation theory and research at the dawn of the twentyfirst century. Annual Review of Psychology 56(1): 485-516.

31. Lazar, A., Zinger, A., Lachterman, B. (2007): The influence of prefeedback selection justice on perceptions of overall procedural justice and organizational attractiveness in a real-life selection procedure. European Journal of Work and Organizational Psychology 16(1): 94-109.

32. Leow, K.L., Khong, K.W. (2009): Organizational Commitment: The study of organizational justice and leader member exchange (LMX) among auditors in Malaysia. International Journal of Business and Information 4(2): 161-198.

33. Lo, M.C., Ramayah, T., Hui, J.K.S (2006): An investigation of leader member exchange effects on organizational citizenship behaviour in Malaysia. Journal of Business and Management 12: 5-23.

34. Meyer, J., Stanley, D., Herscovich, L., Topolnytsky, L. (2002): Affective, continuance, and normative commitment to the organization: A meta-analysis of antecedents, correlates, and consequences. Journal of Vocational Behaviour 61(1): 20-52.

35. Mohd. Nasurdin, A., Soon, L. K. (2011): Organizational justice, age, and performance connection in Malaysia. International Journal of Commerce and Management 21(3): 273-290.

36. Moorman, R.H., Blakely, G.L. (1995): Individualism-Collectivism as an individual difference predictor of organisational citizenship behaviour. Journal of Organisational Behaviour 16(2): 127-142.

37. Moorman, R.H. (1991): Relationship between organizational justice and organizational citizenship behaviour: Do fairness perceptions influence employee citizenship? Journal of Applied Psychology 76(6): 845-855.

38. Murphy, G., Athanasou, J., King, N. (2002): Job satisfaction and organizational citizenship behaviour: A study of Australian human-service professionals. Journal of Managerial Psychology 17(4): 287-297.

39. Nadiri, H., Tanova, C. (2010): An investigation of the role of justice in turnover intentions, job satisfaction, and organizational citizenship behaviour in hospitality industry. International Journal of Hospitality Management 29(1): 33-41.

40. Organ, D. W., Podsakoff, P. M., MacKenzie, S. B. (2006): Organizational Citizenship Behaviour: Its Nature, Antecedents, and Consequences. Thousand Oaks, CA: Sage Publications.

41. Organ, D.W., Moorman, R.H. (1993): Fairness and organizational citizenship behaviour: What are the connections? Social Justice Research 6(1): 5-18.

42. Organ, D.W., Ryan. K. (1995): A meta-analytic review of attitudinal and dispositional predictors of organizational citizenship behaviour. Personnel Psychology 48(4): 775-802.

43. Organ, D.W. (1977): A reappraisal and reinterpretation of the satisfaction-causes-performance hypothesis. Academy of Management Review 2(1): 46-53.

44. Organ, D.W. (1988a): Organizational Citizenship Behaviour: The Good Solider Syndrome. Lexington, MA: Lexington Books.

45. Organ, D.W. (1988b): A restatement of the satisfaction-performance hypothesis. Journal of Management 14(4): 547-557. 
46. Organ, D.W. (1990) The motivational basis of organizational citizenship behaviour. Research in Organizational Behaviour 12(1): 43-72.

47. Organ, D.W. (1997): Organizational citizenship behaviour: It's construct clean-up time". Human Performance 10(2): 85-97.

48. Othman, R. A., Rashida, H., Noor A., Rosmah, M. (2005): Psychological contract violation and organizational citizenship behaviour. Gaja Mada International Journal of Business 7: 325-349

49. Podsakoff, P.M., MacKenzie, S.B., Moorman, R.H., Fetter, R. (1990): Transformational leader behaviours and their effects on followers' trust in leader, satisfaction, and organizational citizenship behaviours. The Leadership Quarterly 1(2): 107-142.

50. Podsakoff, P.M., MacKenzie, S.B., Paine, J.B., Bachrach, D.G. (2000): Organizational citizenship behaviours: A critical review of the theoretical and empirical literature and suggestions for future research. Journal of Management 26(3): 513-563.

51. Price, J.L., Mueller, C.W. (1986): Handbook of Organizational Measurement. Marshfield, Mass: Pittman. Robinson, S.L., Morrison, E.W. (1995): Psychological contracts and the OCB: The effect of unfulfilled obligations on civic virtue behaviour. Journal of Organizational Behaviour 16(3): 289-298.

52. Schaubroeck, J., May, D.R., Brown, F.W. (1994): Procedural justice explanations and reactions to economic hardship: A field experiment. Journal of Applied Psychology, 79(3): 455-460.

53. Skarlicki, D.P., Folger, R. (1997): Retaliation in the workplace: The roles of distributive, procedural, and interactional justice. Journal of Applied Psychology 82(3): 434-443.

54. Skarlicki, D.P., Latham, G.P. (1997): Leadership training in organizational justice to increase citizenship behaviour within a labor union: A replication. Personnel Psychology 50(3): 617-633.

55. Skarlicki, D.P. and Latham, G.P. (1996): Increasing citizenship behaviour within a labor union: A test of organizational justice theory. Journal of Applied Psychology 81(2): 161-169.

56. Smith, C.A., Organ, D.W., Near, J.P. (1983): Organizational citizenship behaviour: Its nature and antecedents. Journal of Applied Psychology 68(4): 653-663.

57. Spector, P.E., Dwyer, D.J., Jex, S.M. (1988): Relation of job stressors to affective, health, and performance outcomes: A comparison of multiple data sources. Journal of Applied Psychology 73(1): 11-19.

58. Sweeney, P.D., McFarlin, D.B. (1993): Workers' evaluations of the 'ends' and the 'means': An examination of four models of distributive and procedural justice. Organizational Behaviour and Human Decision Processes 55(1): 23-40.

59. Tansky, J.W. (1993): Justice and organizational citizenship behaviour: What is the relationship? Employee Responsibilities and Rights Journal 6(3): 195-207.

60. Tyler, T. R., Blader, S. L. (2003): The group engagement model: Procedural justice, social identity, and cooperative behaviour. Personality and Social Psychology Review 7: 349-361.

61. Williams, L.J., Anderson, S.E. (1991): Job satisfaction and organizational commitment as predictors of organizational citizenship and in-role behaviours. Journal of Management 17(3): 601-617.

62. Yilmaz, K. and Tasdan, M. (2009): Organizational citizenship and organizational justice in Turkish primary schools. Journal of Educational Administration 47(1) http://dx.doi.org/10.1108/09578230910928106 
